\title{
Pedeseta obljetnica transplantacije bubrega u Rijeci
}

The fiftieth anniversary of kidney transplantation programme in Rijeka

\author{
Željko Fučkar ${ }^{1,2}$, Josip Španjol ${ }^{1,2}$, Dean Markić ${ }^{1,2^{*}}$
}

\begin{abstract}
Sažetak. Pripreme za transplantaciju bubrega počele su osnivanjem centra za hemodijalizu i započinjanjem programa eksperimentalne kirurgije. $U$ transplantacijski program je bio uključen multidisciplinarni tim, te je konačno 30 . siječnja 1971. godine u našem centru učinjena prva uspješna transplantacija bubrega u Hrvatskoj i tadašnjoj Jugoslaviji. Kroz svih pet desetljeća transplantacijski program je predstavljao ponos riječke medicine, a njegov razvoj je sa sobom povukao razvoj niza medicinskih disciplina. Danas je Klinika za urologiju Referentni centar za transplantaciju bubrega u Republici Hrvatskoj. U ovom preglednome radu ukratko ćemo prikazati povijesni razvoj kao i stručna i znanstvena dostignuća koja su pratila program transplantacije bubrega u Rijeci.
\end{abstract}

Ključne riječi: povijest transplantacije; transplantacija bubrega; ultrazvuk; završni stadij kroničnog zatajenja bubrega

\begin{abstract}
The foundation of hemodialysis center and programme of experimental surgery was basis for kidney transplantation programme in Rijeka. The multidisciplinary team was included in the transplantation programme and the first kidney transplantation was performed on January $30^{\text {th }} 1971$. This was the first kidney transplantation in Croatia and former Yugoslavia. During all five decades this programme was the leader in medicine in Rijeka, and its development was connected with the development of many clinical disciplines. Today, the Department of Urology is Referral Center for kidney transplantation in Croatia. In this review article we will shortly present historical development of our center with professional and scientific achievements during time.
\end{abstract}

Key words: end stage renal disease; history of transplantation; kidney transplantation; ultrasound
${ }^{1}$ Klinika za urologiju, Klinički bolnički centar Rijeka, Rijeka, Hrvatska

${ }^{2}$ Medicinski fakultet Sveučilišta u Rijeci, Rijeka, Hrvatska
*Dopisni autor:

Izv. prof. dr. sc. Dean Markić, dr. med. Klinika za urologiju Medicinskog fakulteta Sveučilišta u Rijeci, Klinički bolnički centar Rijeka, Tome Strižića 3, 51000 Rijeka E-mail: dean.markic@ri.htnet.hr

http://hrcak.srce.hr/medicina 


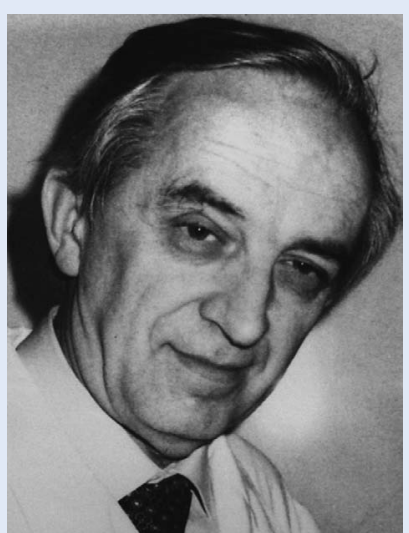

Slika 1.

Prof. dr. sc. Jerko Zec

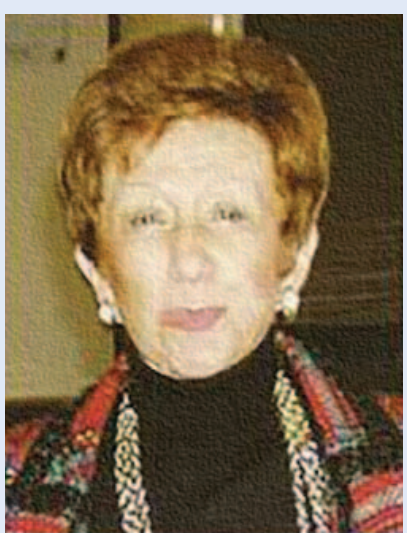

Slika 2.

Prof. dr. sc. Ksenija Vujaklija

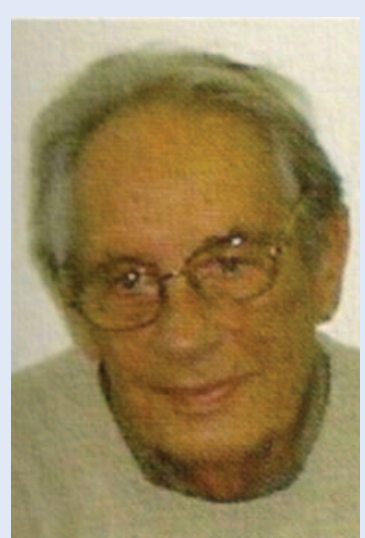

Slika 3.

Mr. ph. Davor Smokvina

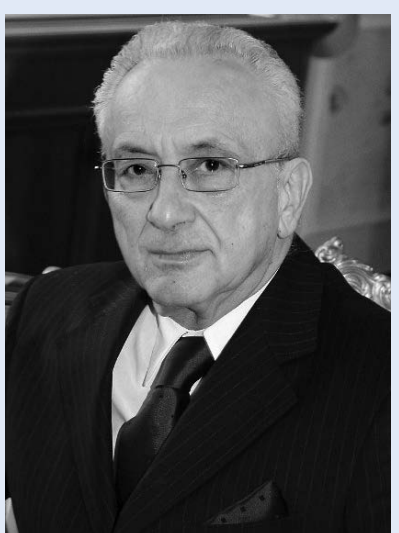

Slika 4.

Prof. dr. sc. Daniel Rukavina

Pripreme za transplantaciju bubrega u Rijeci počele su 1966. godine na animalnim modelima životinja (pas, svinja) na eksperimentalnoj kirurgiji Kirurške klinike na Sušaku, a ujedno se razvijala hemodijaliza (prof. dr. Jerko Zec - slika 1), transfuziologija (prof. dr. Ksenija Vujaklija-Stipanović slika 2) i laboratorijska dijagnostika (mr. ph. Davor Smokvina - slika 3) ${ }^{1,2}$. Imunološke probleme transplantacije bubrega rješavali su liječnici Zavoda za fiziologiju (prof. dr. Šime Vlahović, dr. Daniel Rukavina - slika 4).

Prva transplantacija bubrega sa živog darivatelja učinjena je 30. siječnja 1971., a 15. svibnja 1972. i prva transplantacija s mrtvog darivatelja (slika 5 $-8)^{3,4}$. Ekipa liječnika sa Sušaka predvođena prof. dr. Vinkom Frančiškovićem u razdoblju od 1972. do 1976. učinila je prve transplantacije bubrega u Zagrebu, Sarajevu i Skopju. Liječnici Odjela za urologiju (dr. Petar Orlić, dr. Damir Dimec, dr. Giampaolo Velčić, dr. Miomir Zelić, dr. Željko Fučkar, dr. Miljenko Uravić) bili su svakodnevni dio timova pri bubrežnim transplantacijama, kao i kasnijem praćenju tih pacijenata.

Uz spomenute, uz kliničku problematiku liječenja renalne insuficijencije i renalne transplantacije na urologiji, sudjelovale su i grupe liječnika specijalista s drugih klinika i odjela: nefrolozi (prof. dr. sc. Franjo Čohar, prof. dr. Đurđica Matić-Glažar, prof. dr. sc. Mirjana Gržetić, dr. Željka Merlak), transfuziolozi (prof. dr. sc. Ksenija Vujaklija-Stipanović sa suradnicima: dr. Eja Miculinić-Ivančić, dr. Marija Crnić-Martinović, dr. Marina Fućak i kasnije dr. Nataša Katalinić), imunolozi (prof. dr. sc. Šime Vlahović i njegov tim: prof. dr. sc. Petar Eberhard,

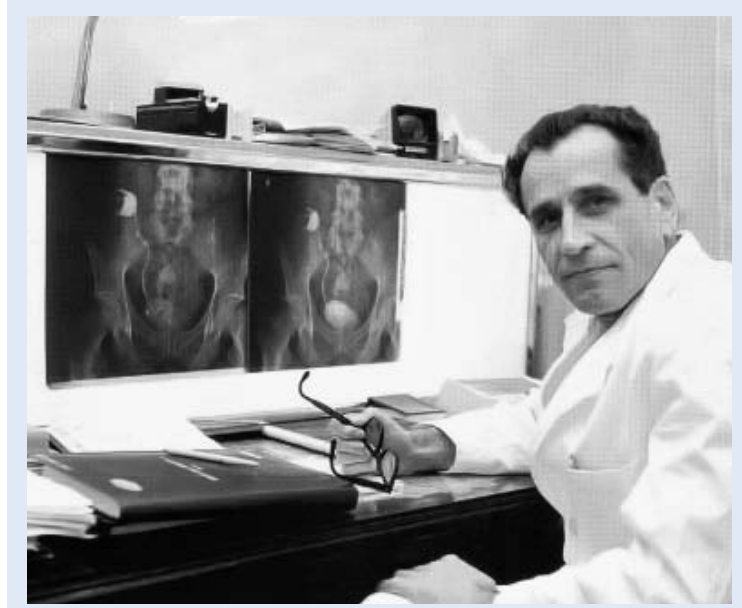

Slika 5. Prof. dr. sc. Vinko Frančišković

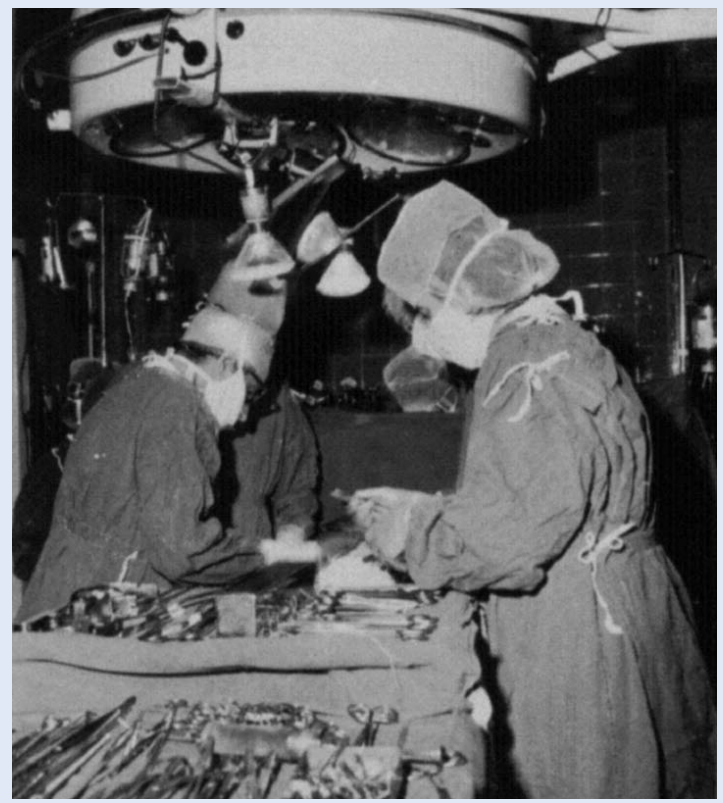

Slika 6. Detalj iz operacijske sale tijekom prve transplantacije bubrega. 
prof. dr. sc. Vlasta Vlahović-Linić, prof. dr. sc. Daniel Rukavina), bakteriolozi (dr. Nikola Gržalja i dr. Đurđica Vukelić) te vrijedna grupa anesteziologa vođena prim. dr. Vlastom Strižić (dr. Dunja Švalba, dr. Branka Dorčić, dr. Alemka Suzanić, dr. Anđelko Đirlić) $)^{1,5}$.

Sjećajući se tih nezaboravno lijepih i uspješnih vremena, kada za sve nas nisu postojale subote, nedjelje, slobodni dani, obiteljski problemi, socijalna situiranost, pripravnosti i sve ono što prati današnji normalni kirurški život, htjeli smo isključivo kvalitetno pomagati pacijentima s kroničnom bubrežnom insuficijencijom, a motiva nam nije nedostajalo. Ta je mlada generacija zasigurno i iznijela većinu transplantacijskog programa na čelu s prof. dr. Vinkom Frančiškovićem.

Rijeka je bila dominantni centar na prostorima bivše Jugoslavije u kojem je prvi put osnovana regionalna organizacija za dijalizu i transplantaciju („Jugotransplant“), koja je od 29. listopada 1973. povezivala sve regionalne centre bivše Jugoslavije transferom znanja u organizacijskom, tehnološkom stručnom i znanstvenom smislu.

$\mathrm{U}$ tim je pionirskim vremenima mnogo najuglednijih jugoslavenskih urologa dolazilo u Rijeku zbog organizacije transplantacije u svojim centrima (Čečuk, Gabrić, Vidović - Zagreb, Bošković - Sarajevo, Vlaški - Skopje, Balabanić - Banja Luka, Adanja - Beograd itd.). U Opatiji je 1978. održan prvi kongres i skupština „Jugotransplanta"1,5.

Godine 1976. učinjena je prva transplantacija bubrega sa žive nesrodne osobe.

Nagli razvoj transplantacije bubrega u Rijeci zahtijevao je i razvoj pratećih kliničkih disciplina $i$ djelatnosti (RTG - prve angiografije transplantata, transfuziologija - tipizacija, laboratorij - nove metode biokemijskih pretraga, mikrobiologija bakterije i virusi u novom okruženju itd.) (slika 9). Transplantacije su snažno pridonijele razvoju transfuziologije, mikrobiologije i virusologije, laboratorijske dijagnostike, imunologije, patologije, rendgenološke dijagnostike, ultrazvuka, eksperimentalne urologije, a osnovan je i Centar za tipizaciju tkiva.

Temeljnu brigu oko pripreme i vođenja poslijetransplantacijskog razdoblja dugi niz godina vodili su vrijedno i uspješno prof. dr. Franjo Čohar i prof. dr. Petar Orlićs-29.

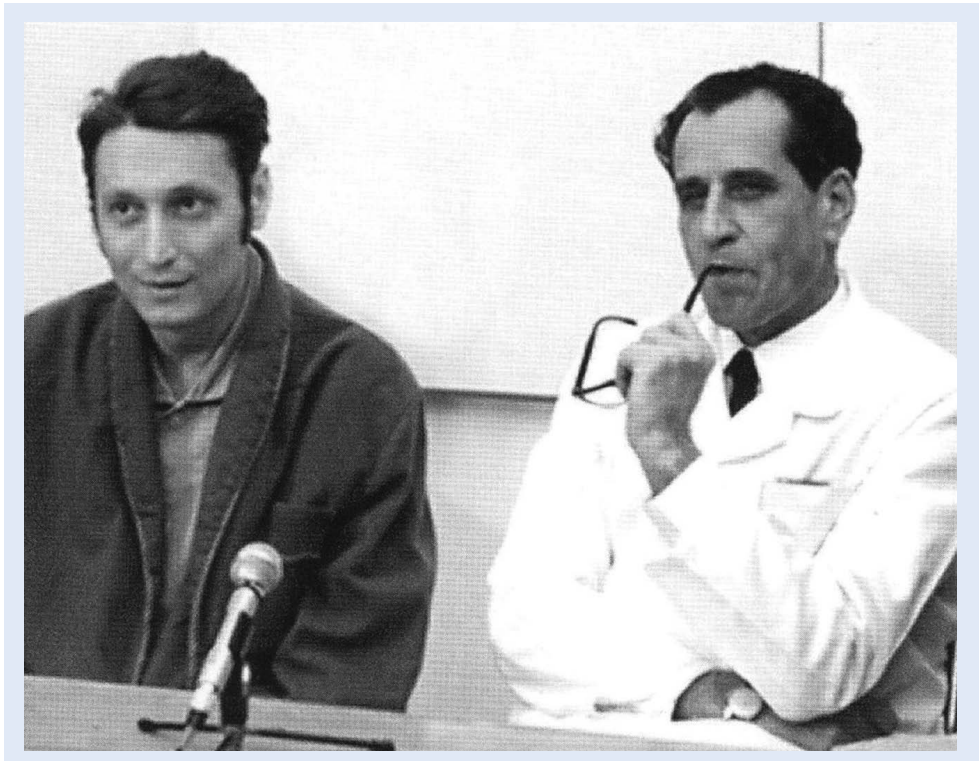

Slika 7. Prof. dr. sc. Vinko Frančišković s prvim transplantiranim pacijentom.

Transplantacijski program u našoj ustanovi, a time i u Hrvatskoj, započeo je 30. siječnja 1971. godine kada smo učinili prvu uspješnu transplantaciju bubrega. Tijekom sljedećih pet desetljeća učinilo smo više od 1100 transplantacija bubrega.

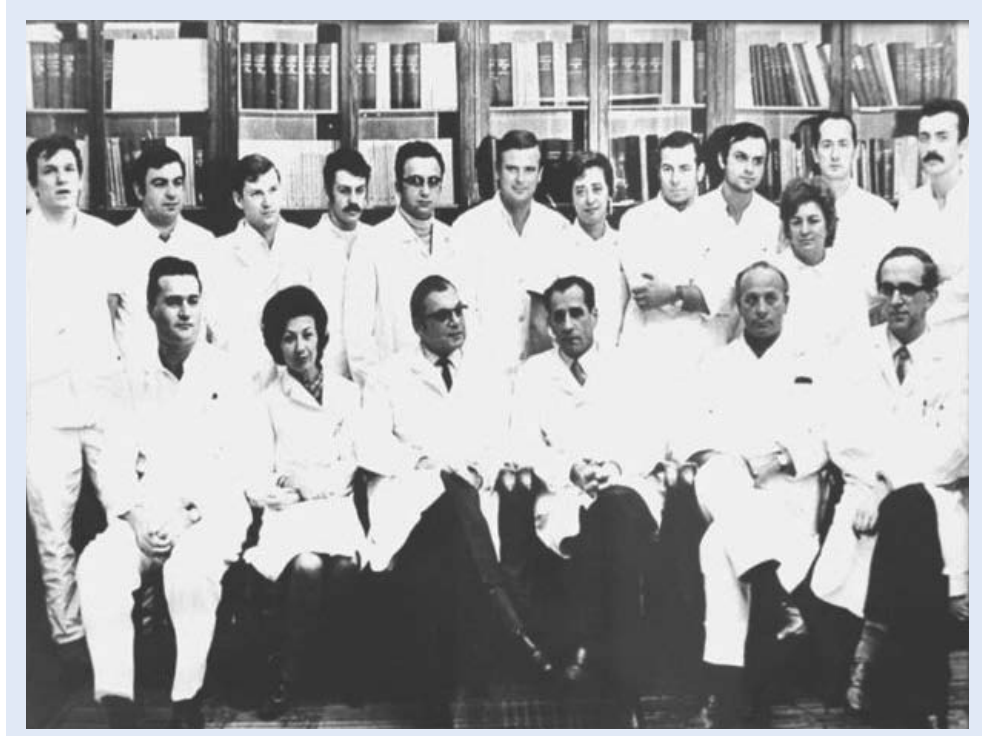

Slika 8. Multidisciplinarni tim s prve transplantacije bubrega. Prvi red slijeva sjede: dr. Petar Orlić, dr. Ksenija Vujaklija-Stipanović (transfuzija), prof. dr. sc. Šime Vlahović (Zavod za fiziologiju, Medicinski fakultet Rijeka), prof. dr. sc. Vinko Frančišković, dr. Tomislav Tićac, dr. Jerko Zec. Drugi red slijeva stoje: dr. Giampaolo Velčić, dr. Miomir Zelić, dr. Damir Dimec, dr. Nikola Gržalja (Zavod za mikrobiologiju), dr. Danijel Rukavina (Zavod za fiziologiju, Medicinski fakultet Rijeka), dr. Ante Šepić, dr. Alenka Suzanić (anesteziologija), dr. Vjerislav Peterković, dr. Duje Vukas, dr. Branimir Budisavljević, dr. Andrej Gudović. 


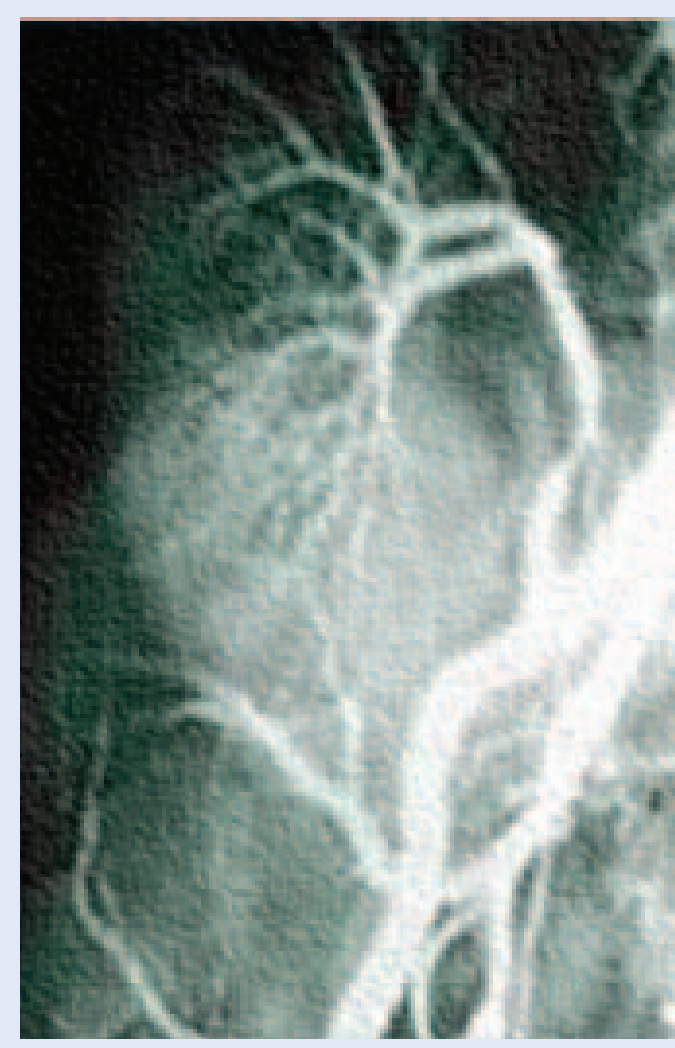

Slika 9. Prva angiografija transplantiranog bubrega iz 1972. godine. Vidljiva je stenoza renalne arterije na anastomozi s arterijom ilijakom internom. Učinjena je kirurška reanastomoza uz dobar učinak.

Prva simultana transplantaciju bubrega i pankreasa napravljena je 21. prosinca 1993. na Sušaku (dr. Miomir Zelić, prof. dr. Petar Orlić, doc. dr. Miljenko Uravić). Uvedeni su i novi transplantacijski zahvati (autotransplantacija bubrega, ortotopna transplantacije bubrega, perfuzija in situ, minimalni invazivni zahvati, ESWL itd. $)^{30-37}$.

Tijekom Domovinskog rata, u kojem su mnogi liječnici s urologije aktivno sudjelovali, transplantacijski program kontinuirano se nastavljao.

Klinika i Katedra za urologiju osnovana je 2005. godine, a 2007. je utemeljen Referentni centar za transplantaciju bubrega MZRH.

Uspjeli smo otvoriti 2008. godine eksperimentalna istraživanja transplantacije bubrega na modelima malih životinja u suradnji sa Zavodom za anatomiju Medicinskog fakulteta u Rijeci.

Unutar transplantacijskog programa „Eurotransplanta" razvio se "senior program", u kojemu uspješno sudjelujemo, a također smo uspješno transplantirali dva bubrega jednom primatelju. Va- lja podsjetiti kako smo prvi put u Hrvatskoj transplantirali dječji bubreg odrasloj osobi, a 2011. godine je učinjena prva ortotopna transplantacija bubrega. Uz to je u našem centru učinjena i uspješna en-bloc transplantacija bubrega, transplantacija kod Jehovinih svjedoka, transplantacija potkovičastog bubrega te transplantacija uz korištenje urinarne derivacije. U rješavanju komplikacija koriste se različiti minimalno invazivni zahvati, prvenstveno iz područja endourologije ${ }^{30-37}$.

Od 2000. do 2010. godine transplantacijski program vodio je prof. dr. Željko Fučkar, potom do 2013. doc. dr. Maksim Valenčić, pa kraće vrijeme pokojni prof. dr. Anton Maričić, a od 2015. program vodi prof. dr. Josip Španjol. Do siječnja 2020. godine učinjeno je 1.174 transplantacija bubrega (812 kadaverična i 362 sa živog darivatelja).

Tijekom godina mijenjala se i temeljna kirurška tehnika transplantacije, gdje smo u prvim godinama radili anastomozu bubrežne arterije na unutarnju art. llijaku, bojeći se infekcije anastomoze (šivalo se multifilamentnim običnim koncem). Proizvodnjom monofilamentnog najlonskog konca različitih debljina i nepodložnih mogućim infekcijama počeli smo rutinski raditi terminolateralne vaskularne anastomoze na vanjskim ilijakalnim arterijama s odličnim rezultatima. Danas to izgleda kao mali, ali vrlo značajni korak u kirurškoj tehnici transplantacije.

Prvi radovi u Jugoslaviji iz konvencijske ultrazvučne dijagnostike transplantiranog bubrega $u$ nas javljaju se u drugoj polovini sedamdesetih godina sa sonografskim opisom akutne krize odbacivanja bubrežnog presatka. Polovinom osamdesetih godina uveden je, prvi put u nas, u istraživanju patologije transplantacije bubrega $i$ intervencijski ultrazvuk. Početkom devedesetih godina prošlog stoljeća počela su sistematska sonografska istraživanja parenhimnih funkcija presađenog bubre$g a^{38-50}$. Pionirski posao počeo je na nezgrapnom ultrazvučnom aparatu s jednostavnim prikazom B-scana, kako bismo 1975. učinili i prve sonografske snimke transplantiranog bubrega (slika $10 \mathrm{i}$ 11).

Na kongresu „Jugotransplanta“ 1978. godine smo prvi put u Jugoslaviji i među prvima u svijetu prikazali mogućnosti ultrazvuka u transplantaciji bubrega ${ }^{49}$. 
Brz i snažan razvoj sonografskih aparata (siva skala i real-time prikaz) otvorili su nove mogućnosti u poslijeoperacijskom praćenju i dijagnostici patologije transplantiranog bubrega, o čemu smo vrlo često izvještavali (slika 12). Početkom osamdesetih godina prošlog stoljeća u KBC-u Rijeka osnovana je Služba za ultrazvučnu dijagnostiku koju je vodila ekipa iz Odjela za urologiju na Sušaku, a posebno se razvila tehnologija biopsije transplantiranog bubrega pod vodstvom ultrazvuka. Dijagnostika poslijeoperacijskih problema i kasnije moguće patologije uglavnom se temeljila na sonografskim nalazima, ne isključujući i ostale kliničke dijagnostičke modalitete.

Prvi projekt iz sonografije u parenhimnih bolesti bubrežnog transplantata (br. 4-01-425) prihvatilo je Ministarstvo znanosti Republike Hrvatske 1992. godine; u cijelosti je uspješno odrađen, a sredstvima iz toga projekta kupljen je i najnoviji Doppler sonografski aparat. Prvi intervencijski zahvati u posttransplantacijskoj patologiji (limfocele, urinomi, hematomi itd.) u Jugoslaviji uspješno su učinjeni na Odjelu za urologiju Klinike za kirurgiju KBC-a Rijeka.

Zašto toliko redaka dajemo ultrazvuku? Našim smo spoznajama i dokazanim istraživanjima uspjeli razlučiti temeljni problem ranih komplikacija $u$ transplantiranih bubrega: radi li se o procesu odbacivanja ili akutnoj tubularnoj nekrozi? Svaki takav entitet ima različitu prognozu i terapiju. Novi aparati su u stanju razlučiti protok na nivou lučnih arterija bubrega, a tu je najizraženija mikropatologija promjena u ranom poslijeoperacijskom razdoblju. Naravno, slijedi biopsija bubrega pod vodstvom ultrazvuka i patohistologijska analiza bioptata.

Ta su dva dijagnostička postupka najsnažnije i najkvalitetnije unaprijedili akutnu dubioznu poslijetransplantacijsku problematiku. Treba se sjetiti kako smo prve free-hand biopsije transplantata slali u Ljubljanu na patohistologijski pregled autobusom redovite linije ljubaznošću vozača, a rezultati bioptata su dolazili za, približno, tri do četiri tjedna. No, od 1994. godine se na Zavodu za patologiju Medicinskog fakulteta u Rijeci sustavno uvodi standardizacija laboratorijske dijagnostike uz stručno osposobljavanje djelatnika za biopsije bubrega, da bi 1998. bio utemeljen nefropatološ-

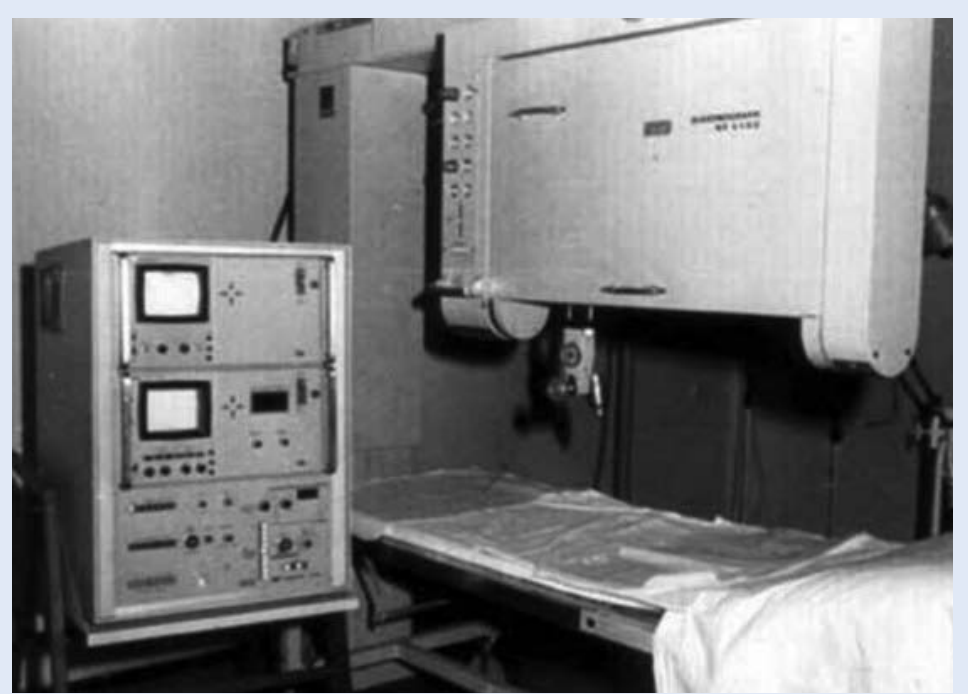

Slika 10. Prvi B-scan ultrazvučni aparat

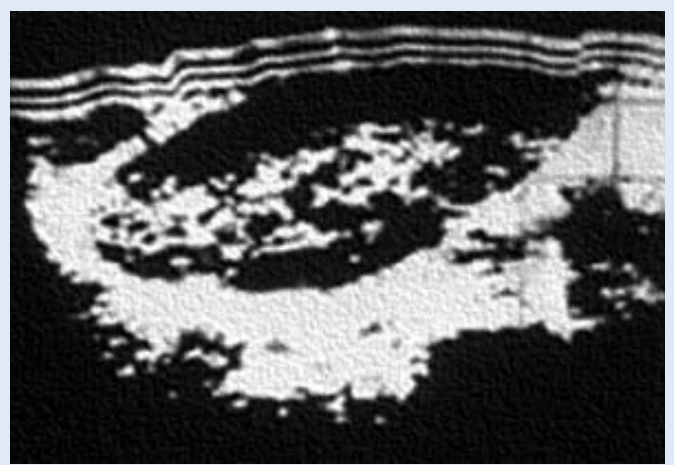

Slika 11. Prva slika transplantiranog bubrega iz 1975. godine.

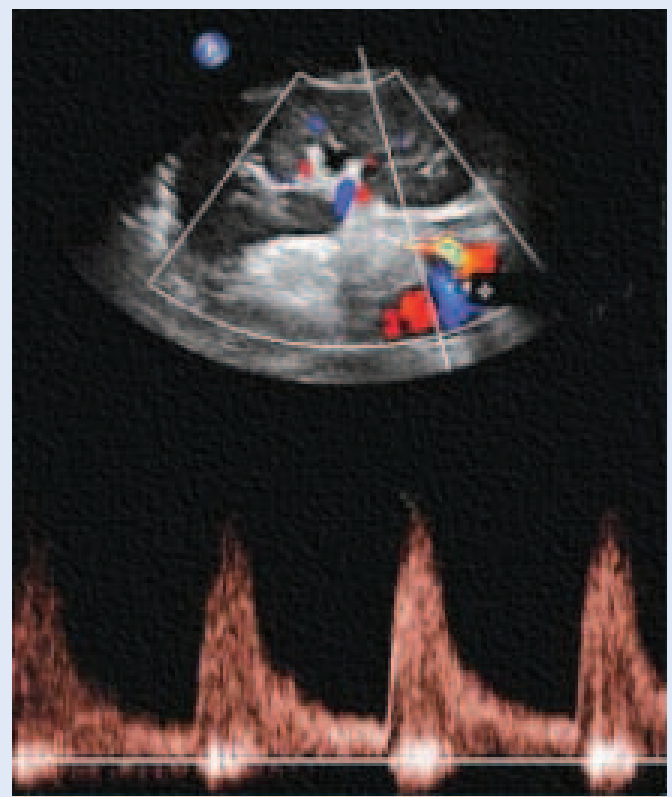

Slika 12. Suvremeni ultrazvučni prikaz transplantata uz korištenje obojenog doplera. 


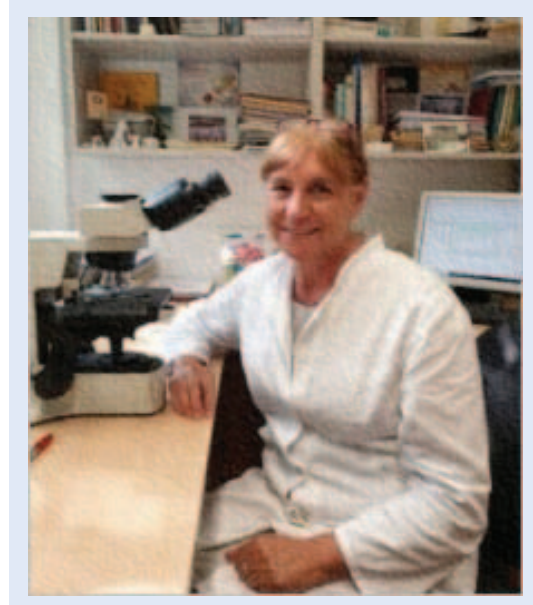

Slika 13. Prof. dr. sc. Gordana Đorđević

Tijekom svih godina transplantacijski program je funkcionirao na principu multidisciplinarnosti uz sinergiju niza kliničkih i pretkliničkih disciplina. Zbog svojih izvanrednih rezultata ponosno nosi naziv Referentnog centra za transplantaciju bubrega u Hrvatskoj.

ki laboratorij za dijagnostiku glomerulopatija $i$ patologiju transplantiranog bubrega. Tako je transplantacijski tim dobio vrlo značajnu podršku u patohistologijskoj dijagnostici na nivou svjetlosne, imunofluorescentne i elektronske mikroskopije. Dugogodišnji kvalitetni razvoj dijagnostike u patohistologiji transplantata, gdje se nalaz biopsije dobiva za 2 - 3 sata, marljivo je i vrhunski odradila, a čini to i danas, prof. dr. Gordana Đorđević (slika 13).

Znanstveno-istraživački rad iz područja transplantacije bubrega uključivao je: 1 samostalni projekt, 3 zajednička projekta, 11 potprojekata, 9 projektnih zadataka, 7 doktorata, 14 magisterija, 11 poglavlja u knjigama, preko 800 radova u našim i stranim časopisima te preko 100 pozvanih predavanja u zemlji i inozemstvu. Nagrade i priznanja uključuju: Nagrade grada Rijeke - 3, Zlatna plaketa grada Rijeke - 1, Srebrna plaketa grada Rijeke - 1, Brončana plaketa grada Rijeke -1 , razna liječnička udruženja -15, studentske udruge - 7 .

Zaključno naglasimo da kroz svih proteklih pedeset godina u našoj ustanovi nije bilo prekida u transplantaciji bubrega, uključujući i ratne godine. Zahvaljujući kontinuiranom radu i stalnom napretku danas naša ustanova ima iskusan tim liječnika različitih specijalnosti koji sudjeluje u obradi, transplantaciji i posttransplantacijskom praćenju pacijenata. Na taj način možemo se uspješno nositi $s$ izazovima koje zahtijeva takvo liječenje.

Izjava o sukobu interesa: Autori izjavljuju da ne postoji sukob interesa.

\section{LITERATURA}

1. Fučkar Ž. Povijest urologije na Sušaku. Rijeka: Digital point, 2006;79-86

2. Markić D, Valenčić $M$, Maričić A, Španjol J, Rački S, Fučkar Ž. Kidney transplantation - successful story started 110 years ago. Acta Med Croatica 2012;66:59-63.

3. Frančišković V, Vlahović Š, Zec J, Orlić P, Peterković V. Transplantacija bubrega - prikaz jednog slučaja. Lijec Vjesn 1971;93:849-57.

4. Markić D, Fučkar Ž, Đorđević G. Transplantacija bubrega. U: Fučkar Ž, Španjol J (ur.) Urologija II (specijalni dio). Rijeka: Medicinski fakultet Rijeka, 2013;431-69.

5. Fučkar Ž. Povijest transplantacije bubrega na Sušaku. Medicina Fluminensis 2010;46:352 9.

6. Zec J. Izbor dijalitičke metode u liječenju akutne i kronične renalne insuficijencije. Rijeka: Medicinski fakultet, 1974. $\mathrm{PhD}$ thesis.

7. Orlić $P$, Velčić $G$, Uravić $M$, Dimec $D$, Vukas $D$, Zelić $M$ et al. Transplantacija bubrega sa živog donora. Zbornik radova I. kongresa Jugoslavenske zajednice za dijalizu i transplantaciju. Rijeka: 1980;327-34.

8. Zec J, Matić-Glažar $Đ$, Zelić $M$, Uravić $M$, Vukas $D$, Čohar $\mathrm{F}$ et al. 14-years of kidney transplantation in Rijeka. Period Biol 1986;88:90-1.

9. Orlić P. Pretransplantacijski status i procjena intenziteta imunosupresije i predviđanja krize odbacivanja. Rijeka: Medicinski fakultet, 1985. PhD thesis.

10. Vukas D. Značenje urinarne infekcije u kliničkoj transplantaciji bubrega. Rijeka: Medicinski fakultet, 1985. $\mathrm{PhD}$ thesis.

11. Frančišković $V$, Orlić $P$, Budisavljević $B$, Vukas $D$, Zelić $M$, Ćuruvija D. Arterijske stenoze nakon transplantacije bubrega. Act Chir lugosl 1985;26:147-8.

12. Šepić $A$, Orlić $P$, Velčić $G$, Vukas $D$, Dimec $D$, Uravić $M$. Reoperacije nakon transplantacije bubrega. Act Chir lugosl 1989;36:219-27.

13. Orlić P, Šepić A, Budisavljević B, Ćuruvija D, Drešćik I, Franulović $B$ et al. Hitna kirurška stanja nakon transplantacije bubrega. Act Chir lugosl 1989;36:111-4.

14. Vukas D, Velčić $G$, Zelić $M$, Dimec D, Uravić M, MatićGlažar Đ. Komplikacije nakon transplantacije bubrega. Radiol lugosl 1987;21:335-8.

15. Šepić A, Orlić P, Vukas D, Ćuruvija D, Dimec D, Fučkar Ž et al. Rane i kasne komplikacije po transplantaciji organa. Hrvatska akademija medicinskih znanosti, Zagreb 1991: 139-48.

16. Orlić P, Čohar F, Dimec D, Fučkar Ž, Gržetić M. Transplantacija bubrega. Radiol lugosl 1987;21:329-33.

17. Zec J, Orlić $P$, Matić-Glažar $Đ$, Dimec $D$, Velčić $G$, Zelić $M$ et al. 14 years of kidney transplantation in Rijeka. Procc of the $1^{\text {st }}$ Congress of Yugoslav Immunologists. Period Biol 1986;881:90-1. 
18. Frančišković $\mathrm{V}$, Čohar F, Strižić V, Vujaklija-Stipanović K, Orlić P. Esperienze del centro trapianti di Fiume. Archivio ed atti della societa Italiana di chirurgia. Padova: Piccin Editore, 1976;//III:173-6.

19. Frančišković $V$, Čohar F. Gudović $A$, Orlić $P$, Smokvina $D$, Strižić $V$ et al. Postoperativna iskustva nakon 40 transplantacija bubrega. Lijec Vjesn 1975;97:440-7.

20. Orlić $P$, Dimec $D$, Fučkar Ž, Uravić $M$, Matić-Glažar $\oplus$, Čohar $\mathrm{F}$ et al. Transplantacija bubrega u Kirurškoj klinici KBC Rijeka - sadašnje stanje i perspektive. Lijec Vjesn 1987;109:453-7.

21. Matić-Glažar $\oplus$, Miculinić $E$, Vujaklija-Stipanović $K$, Orlić $\mathrm{P}$, Vukas D, Zec J. Hb-antigenemia and survival of patients and grafts after kidney transplantation. Perid Biol 1986;88:545-60.

22. Čohar F, Gržetić $M$, Vukas $D$, Orlić $P$, Dimec $D$, Zec J. The outcome of pregnancy after renal transplantation. Period Biol 1988;90:547-8.

23. Čohar F. Imunosupresivna terapija u transplantaciji bubrega. Rijeka: Medicinski fakultet, 1980. PhD thesis.

24. Čohar F, Zec J, Stipanić A, Beleznay O, Frančišković V. Tok bolesti, trudnoća i porođaj bolesnice s transplantiranim bubregom. Lijec Vjesn 1977;99:178-80.

25. Čohar F. Imunosupresija u transplantaciji bubrega. Lijec Vjesn 1977;10:126-8.

26. Čohar F, Gržetić M, Lovasić I, Zec J. Akutno zatajenje bubrega nakon renalne angiografije kod dva bolesnika $s$ transplantiranim bubregom. Act Facult Med Flum 1978;15:37-41.

27. Vujaklija-Stipanović K, Matić-Glažar $Ð$, Vukas D, Crnić-Martinović $\mathrm{M}$, Fućak $\mathrm{M}$ et al. Renal transplantation in war time; Experience of single centre. Abstract Book 10th CTS Anniversary and 100.000 CTS transplants. Heidelberg 1992;10-13.

28. Orlić P, Šepić A, Budisavljević B, Ćuruvija D, Dimec D, Franulović $B$ et al. Emergency surgical conditions after renal transplantation. Acta Chir lugosl 1989;36:111-4.

29. Orlic $P$, Vukas $D$, Dreščik I, Ivančić $A$, Blečić $G$, Budiselić $B$ et al. Vascular complications after 725 kidney transplantations during 3 decades. Transplant Proc 2003;35:13814.

30. Markić $D$, Valenčić $M$, Velčić $G$, Maričić $A$, Oguić $R$, Sotošek $S$ et al. Transplantacija bubrega u bolesnika $S$ urinarnom diverzijom. Lijec Vjesn 2009;131:308-11.

31. Markić D, Španjol J, Oguić R, Krpina K, Gršković A, Rahelić $\mathrm{D}$ et al. Transplantacija bubrega u bolesnika $\mathrm{s}$ prethodno učinjenom urinarnom derivacijom i augmentacijom mokraćnog mjehura. Acta Med Croatica 2019;73:261-6.

32. Markić $D$, Oguić $R$, Krpina K, Gršković A, Vukelić I, Rački S et al. Kidney transplantation using a colon pouch (Mainz pouch III): a case report. Croat Med J 2019;90:233-7.

33. Markić $D$, Valenčić $M$, Maričić $A$, Oguić $R$, Sotošek $S$, Španjol J et al. Dual kidney transplantation. Medicina Fluminensis 2011;47:316-20.
34. Markić D, Španjol J, Krpina K, Gršković A, Rahelić D, Rubinić $\mathrm{N}$ et al. Ortotopna transplantacija bubrega naša prva iskustva. Acta Med Croatica 2014;68:172-5.

35. Markić $D$, Oguić $R$, Krpina K, Gršković $A$, Rahelić $D$, Rubinić $\mathrm{N}$ et al. Kidney transplantation using split horseshoe kidney - a case report. Lijec Vjesn 2019;141:24-8.

36. Markić D, Krpina K, Ahel J, Gršković A, Španjol J, Rubinić $\mathrm{N}$ et al. Treatment of kidney stone in a kidney-transplanted patient with mini-percutaneous laser lithotripsy: a case report. Case Rep Nephrol Dial 2016;6:26-31.

37. Markić $D$, Valenčić $M$, Gršković $A$, Španjol J, Sotošek $S$, Fučkar Ž et al Extracorporeal shockwave lithotripsy of ureteral stone in a patient with en bloc kidney transplantation: a case report. Transplant Proc 2011;43(5):2110-2.

38. Mozetič V, Fučkar Ž. Sonografija u transplantaciji bubrega. In: Fučkar Ž (ed). Sonografija urogenitalnog sustava: I dio. Rijeka: Digital point, 1998;241-9.

39. Mozetič V. Uloga indeksa otpora u kolor doppler praćenju perfuzije transplantata bubrega. Medicinski fakultet Rijeka, 1997. Magistarski rad.

40. Fučkar Ž. Kidney transplantation. In: Kurjak A, Fučkar Ž, Gharbi HA (eds). Atlas of abdominal and small parts. Zagreb: Naprijed, 1990;256-62.

41. Fučkar Ž. Ehosonografija transplantiranog bubrega $\mathrm{i}$ ultrazvučne karakteristike odbacivanja transplantata. Lijec Vjesn 1980;102:131-4.

42. Fučkar Ž, Maričić $A$, Mozetič $V$, Dimec $D$, Miletić $D$. Contribution to the treatment of lymphoceles after renal transplantation. Radiol Oncol 1993;27:27-30.

43. Fučkar Ž, Mozetič V, Dimec D, Šustić A. Intervencijski ultrazvuk u transplantaciji bubrega. I. hrvatski kongres za nefrologiju, dijalizu i transplantaciju. Zagreb 1994;41:164.

44. Fučkar Ž, Dimec D, Dujmović M, Lovasić I, Gajić M. Primjena ultrazvuka u patologiji transplantiranog bubrega. Radiol lugosl 1985;19:177-82.

45. Mozetič V, Fučkar Ž, Šustić $A$, Miletić $D$, Orlić $P$, Oguić R.Individual value of resistance index in duplex color Doppler follow up of kidney transplant perfusion. J UItrasound Med 1996;15:82.

46. Miletić $D$, Fučkar Z, Šustić A, Mozetič V, Smokvina A, Stančić M. Resistance and pulsatility indices in acute renal obstruction. J Clin Ultrasound 1998;26:79-84.

47. Fučkar Ž, Dimec D, Mozetič V. Osobna iskustva u intervencijskom ultrazvuku u transplantaciji bubrega. Zbornik radova I. kongresa urologa Hrvatske, Zagreb 1995.

48. Mozetič V, Fučkar Ž, Vlahović A, Orlić L, Čohar F, Girotto I. Duplex color Doppler sonography of the postbiopsy renal transplant arteriovenous fistula. Medicina 1993;29; 69-71.

49. Fučkar Ž, Orlić P, Matić-Glažar Đ. Mogućnosti i granice ultrazvučne dijagnostike u pripremi i postoperativnom toku bolesnika s transplantiranim bubregom. Zbornik radova I. kongresa "Jugotransplanta", Opatija, 1978;345-57.

50. Fučkar Ž. Mogućnosti ehosonografije u transplantaciji bubrega. Act Chir lugosl 1981;28:377-81. 